Historical intensity VIII earthquakes along the Rhone valley (Valais, Switzerland) Primary and secondary effects

\author{
Journal Article \\ Author(s): \\ Fritsche, Stefan; Fäh, Donat; Schwarz-Zanetti, Gabriela \\ Publication date: \\ 2012-06 \\ Permanent link: \\ https://doi.org/10.3929/ethz-b-000061304
}

Rights / license:

In Copyright - Non-Commercial Use Permitted

Originally published in:

Swiss Journal of Geosciences 105(1), https://doi.org/10.1007/s00015-012-0095-3 


\title{
Historical intensity VIII earthquakes along the Rhone valley (Valais, Switzerland): primary and secondary effects
}

\author{
Stefan Fritsche · Donat Fäh • Gabriela Schwarz-Zanetti
}

Received: 26 September 2010/ Accepted: 11 January 2012/Published online: 16 May 2012

(C) Swiss Geological Society 2012

\begin{abstract}
In recent years the upper Rhone Valley has been one of the most intensively investigated regions by the Swiss Seismological Service. The high seismicity in the region encourages research in the seismological field and one main focus has been historical seismology. This report presents the state of the art of our historical investigations by giving an overview of the effects of four damaging earthquakes with intensity larger than VII, for which a fairly large number of documents could be found and analyzed. The overview includes the events of 1584 (Aigle, epicentral intensity VIII), 1755 (Brig, epicentral intensity VIII), 1855 (Visp, epicentral intensity VIII), and 1946 (Sierre, epicentral intensity VIII for the main shock and intensity VII for the largest aftershock). The paper focuses mainly on primary and secondary effects in the epicentral region, providing the key data and a general characterization of the event. Generally, primary effects such as the reaction of the population and impact on buildings took more focus in the past. Thus building damage is more frequently described in historic documents. However, we also found a number of sources describing secondary effects such as landslides, snow avalanches, and liquefaction. Since the sources may be useful, we include citations of these documents. The 1584 Aigle event, for example, produced exceptional movements in Lake Geneva, which
\end{abstract}

Editorial handling: A. Hirt and A.G. Milnes.

Electronic supplementary material The online version of this article (doi:10.1007/s00015-012-0095-3) contains supplementary material, which is available to authorized users.

S. Fritsche $\cdot$ D. Fäh $(\bowtie) \cdot$ G. Schwarz-Zanetti

Schweizerischer Erdbebendienst, Sonneggstr. 5,

8092 Zurich, Switzerland

e-mail: donat.faeh@sed.ethz.ch can be explained by an expanded sub aquatic slide with resultant tsunami and seiche. The strongest of the aftershocks of the 1584 event triggered a destructive landslide covering the villages Corbeyrier and Yvorne, VD. All macroseismic data on the discussed events are accessible through the webpage of the Swiss Seismological Service (http://www.seismo.ethz.ch).

Keywords Historical earthquakes - Switzerland · Building damage - Landslides - Snow avalanches · Tsunami $\cdot$ Seiche

\section{Introduction}

The region of interest is the Canton of Valais and parts of the neighbouring Canton of Vaud in western Switzerland. The region is characterized by the Rhone valley that cuts through the western Alps in an ENE-WSW direction, turning sharply to $\mathrm{N}-\mathrm{S}$ at Martigny (Fig. 1). To the north, the valley is restricted by the Aar massif, to the south by the Penninikum. The valley's genesis is strongly related to the interaction between these two tectonic units. The historical and current seismic activity is a consequence of this ongoing process.

Compared with the rest of Switzerland, the region shows an increased seismic hazard: damaging earthquake events thus have much higher recurrence rates in the Valais region (Giardini et al. 2004; Fäh et al. 2011a). For the last half millennium a magnitude 6 event is known to have occurred every century, with impressive consistency. Regarding magnitude 5 events, a recurrence rate of about 30-50 years is apparent over the last three hundred years.

The historical seismicity of the Valais region has been repeatedly investigated. During the last 10 years these 


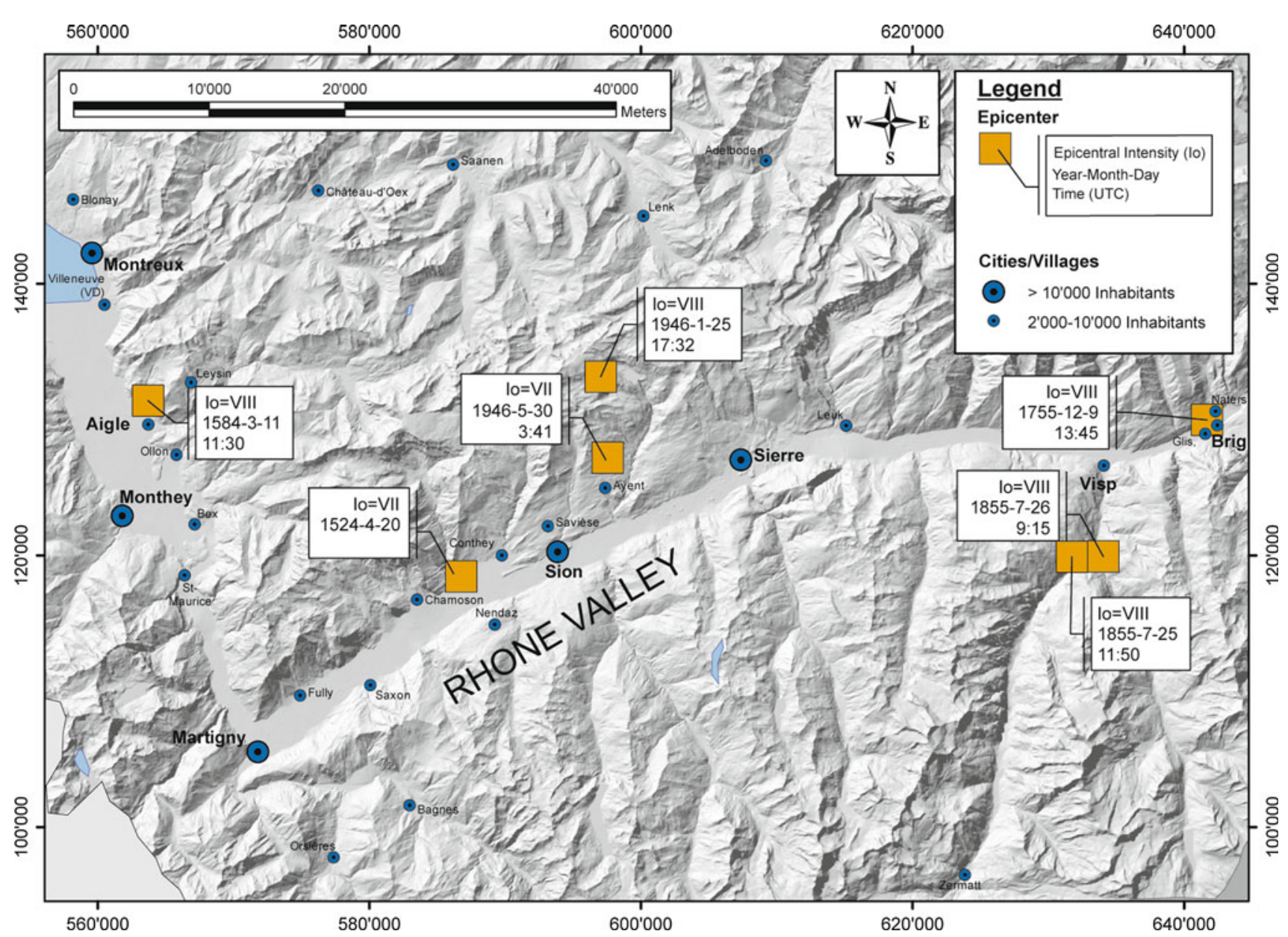

Fig. 1 Overview of the epicenter locations of the earthquakes discussed, together with the 1524 event for which only little information is available

investigations have been broadened and intensified for the known strong events in 1584 (Aigle), 1755 (Brig), 1855 (Visp), and 1946 (Sierre). The base for these investigations was a thorough search through important archives and documents. In the process of these investigations a fifth event of similar size was discovered in the Valais: the 1524 Ardon earthquake (Io $=$ VII, Ix = VIII, $\mathrm{Mw}=5.8$, see SchwarzZanetti and Fäh 2011; Fäh et al. 2011a). Due to the rather weak documentation of primary and secondary effects, the 1524 event is not discussed in this summary. Earlier, medieval events of this dimension have so far not been identified in historical sources originating from the Valais region (Gisler et al. 2007). A few hints regarding damaged buildings could not be correlated with a seismic event and are still under investigation (Schwarz-Zanetti and Fäh 2011).

During investigation we analyzed a wide variety of documents, e.g. chronicles, administration documents, newspaper articles, diaries and scientific articles. The status of source material at hand can be described as follows: more recent earthquakes are in general better documented than events that took place further in the past. To large part this is simply a consequence of the increasing literacy over time. Moreover, it is more likely that ancient written records have been lost over time compared to more recently written documents. However, in particular cases, this is not always true. The 1855 earthquake in the vicinity of Visp, for example, is much better documented than the 1946 Sierre event, since the most significant document for this earthquake is currently untraceable. Parallel to the tendency of increasing availability of data towards the present, the contemporary interpretation of the earthquake phenomena has a strong influence on the type of information that is reported. Earthquakes that were interpreted as a punishment by God for example, result in thoughts and considerations that are different from examinations of this phenomenon in terms of the emerging sciences. The latter tend to deal with the topic in a way that is structurally closer to the present understanding of seismic activity and its aftermath. Quantification and classification of characteristic earthquake effects, for example are usually intrinsic 
elements in this type of documentation. Required information is thus accessible with comparatively low interpretational effort.

Despite wide differences in the content of the historical sources, it was possible to resolve characteristics and details of the aftermath of a number of large earthquakes (see Fig. 1). These are the events of 1584 (Aigle I = VIII, see Schwarz-Zanetti 2008a; Schwarz-Zanetti and Fäh 2011), 1755 (Brig I = VIII, see Gisler et al. 2004; Gisler 2008; Gisler and Fäh 2011), 1855 (Visp I = VIII, see Fritsche et al. 2005, 2006; Gisler and Fäh 2011), and 1946 (Sierre I = VIII and I = VII, Fritsche and Fäh 2009). The present paper provides a summary of these publications focusing on the main characteristics of the observed primary and secondary effects. Primary effects are the impact on human beings and buildings, secondary effects are landslides, snow avalanches, liquefaction, as well as tsunamis and seiches. For details and specific questions we refer to the publications referenced in the respective sections, and to the information available for the earthquake catalogues of Switzerland, ECOS-02 (Fäh et al. 2003), and ECOS-09 (Fäh et al. 2011a).

\section{Major events in the Valais (1584-present)}

\subsection{The 1584 event in Aigle}

\subsubsection{Overview}

The 1584 earthquake series consisted of the main shock on March 11 with epicentral intensity Io of VIII (Table 1), and about 25 aftershocks most of them with unknown intensity during the following days. Details of the historical evaluation of the event can be found in Schwarz-Zanetti and Fäh (2011). Generally the documentation is fragmentary for this event: only few historical sources contain data regarding the damage distribution, none of them in a systematic way. Damage is mainly known in localities along the north-eastern shore of Lake Geneva. A few other cases of damage are known for the surrounding region (Fig. 2). According to the distribution of known effects, the epicenter of the events is assumed to be in the region of Aigle (VD). The earthquake is of utmost importance since it provides insights into a part of the earthquake history of Switzerland at a time when historic sources are rare. Moreover, this fact becomes even more evident since the 1584 event is the cause of two important cases of secondary effects that provoked strong impact: a tsunami wave and seiche in eastern Lake Geneva and a large rock fall from the Tour d'Aï covering the villages Corbeyrier and Yvorne (Fig. 2).

\subsubsection{Primary effects}

Cases of damage for which the location and the precise extent of loss are known are almost non-existent. Information in general is very uncertain and needs to be assessed with caution. A historical report regarding Chillon castle (near Montreux) makes clear, that this building suffered damage on several walls and roofs that had, according to this report, to be repaired immediately. The expenses of the owners of the castle in the following years show that the roof of a tower, battlements and parts of the façade were repaired soon after the event. For the villages near the Chillon castle few reports about damaged buildings exist although according to a contemporary report, some old buildings collapsed. There is a hint that the vault

Table 1 Summary of the 1584 event near Aigle

\begin{tabular}{|c|c|c|c|c|c|}
\hline \multirow[t]{2}{*}{ Location } & Name & $\mathrm{CHX}$ & $\mathrm{CHY}$ & Lat. & Lon. \\
\hline & Aigle (VD) & 563,683 & 131,399 & 46.33 & 6.97 \\
\hline Date/time (UTC) & \multicolumn{2}{|l|}{ March 11, 1584} & \multicolumn{3}{|c|}{ 11:30 a.m. } \\
\hline Intensity & \multicolumn{2}{|c|}{ Epicentral intensity (Io): VIII } & \multicolumn{3}{|c|}{ Maximum intensity (Ix): VIII } \\
\hline Magnitude (Mw) & \multicolumn{5}{|l|}{5.9} \\
\hline Effects & \multicolumn{2}{|l|}{ Primary: known } & \multicolumn{3}{|c|}{ Secondary: known } \\
\hline Level of documentation & \multicolumn{5}{|c|}{$\begin{array}{l}\text { Well documented for the period. One reason for this is the disastrous rockslide triggered by the strongest aftershock. } \\
\text { No systematic historical sources describe the loss }\end{array}$} \\
\hline Remarks & \multicolumn{5}{|c|}{$\begin{array}{l}\text { Marche } 11 \text {, a seiche and tsunami occurred in Lake Geneva. A disastrous rockslide followed on March } 14,1584 \text {. The } \\
\text { rockslide, which killed around } 320 \text { people and a livestock of several hundred animals, was triggered by an aftershock }\end{array}$} \\
\hline \multirow[t]{4}{*}{ References } & \multicolumn{5}{|c|}{ Schwarz-Zanetti 2008a } \\
\hline & \multicolumn{5}{|c|}{ Schwarz-Zanetti and Fäh 2011} \\
\hline & \multicolumn{5}{|l|}{ Heim 1932} \\
\hline & \multicolumn{5}{|l|}{ Loizeau 1991} \\
\hline
\end{tabular}

Location, date and time, intensity and magnitude are taken from ECOS-09 (Fäh et al. 2011a). The abbreviation CHX/CHY stands for the coordinates of the Swiss coordinate system (or Swiss grid) and is also used in Tables 2, 3 and 5 


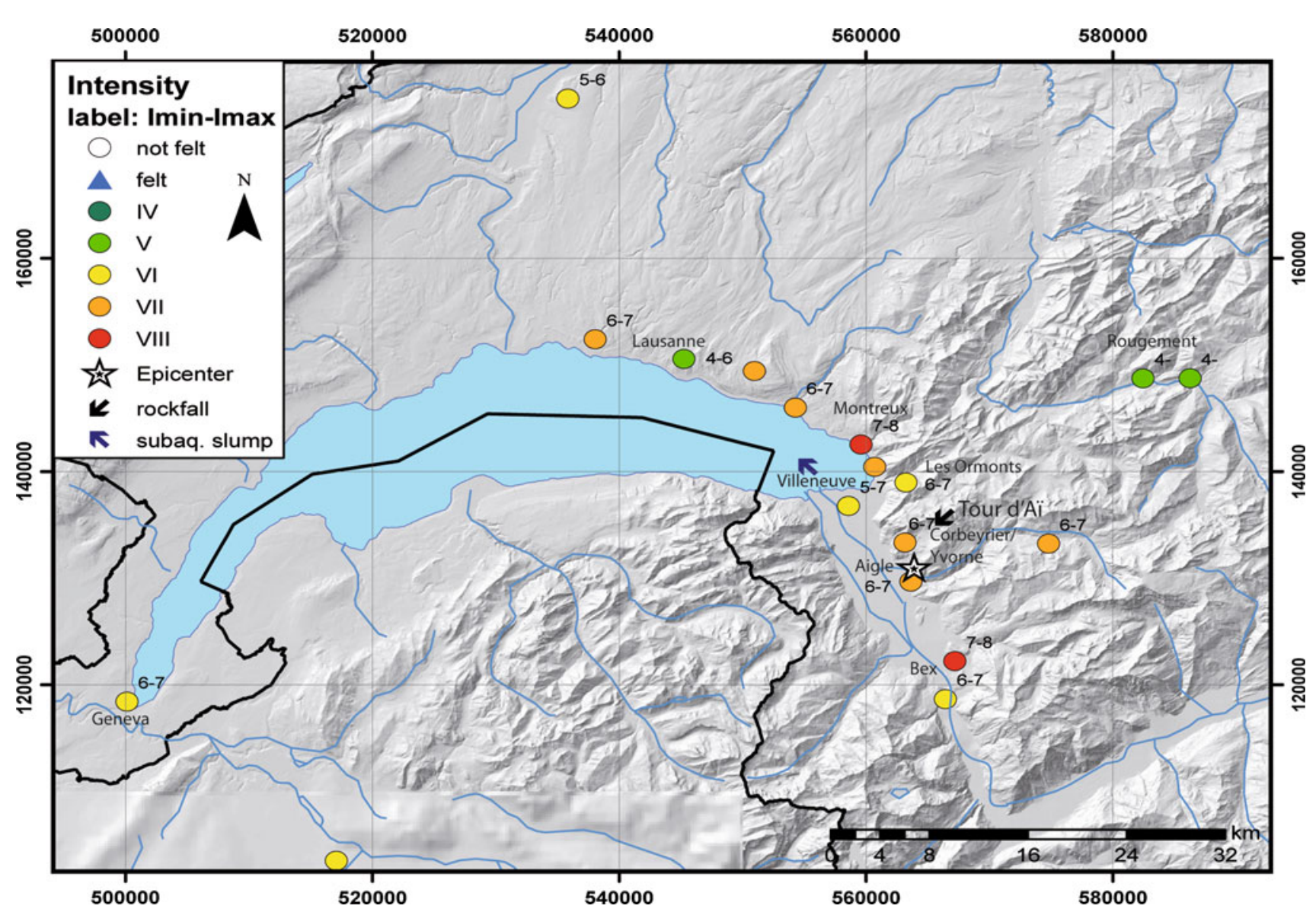

Fig. 2 Macroseismic field and secondary effects of the 1584 event near Aigle (main shock March 11, aftershock March 14). Arabic numbers indicate uncertainties of observed intensities

Table 2 Summary of the 1755 event near Brig

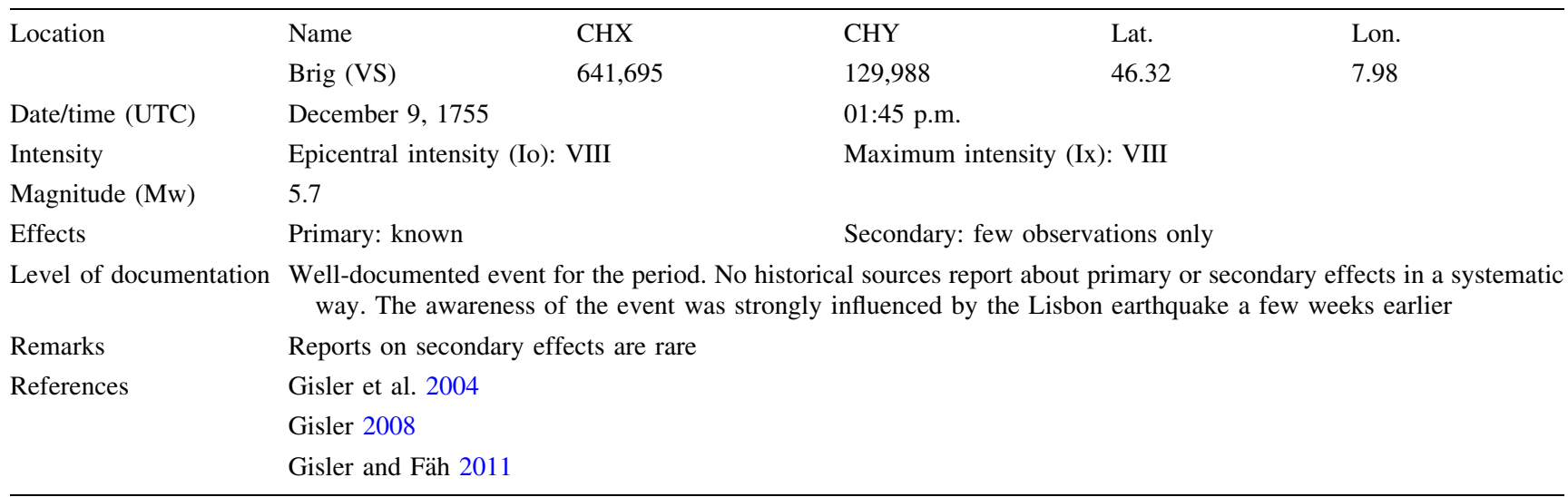

Location, date and time, intensity and magnitude are taken from ECOS-09 (Fäh et al. 2011a)

of the church in Glion (near Montreux) collapsed, killing a woman and injuring several others. The latter is the only information regarding casualties as an immediate consequence of the ground shaking. Some building collapses also occurred in Lausanne and Geneva without being described in detail. Further damage is known to have occurred in the northeast (Saanen, Rougemont and Les Ormonts) where, according to a short report, a church and a rectory collapsed. For Aigle, in the immediate vicinity of the supposed epicenter, no severe damage is known. A contemporary report refers to the destruction of 50-60 chimneys. $10 \mathrm{~km}$ to the south of Aigle, in Bex, it is 


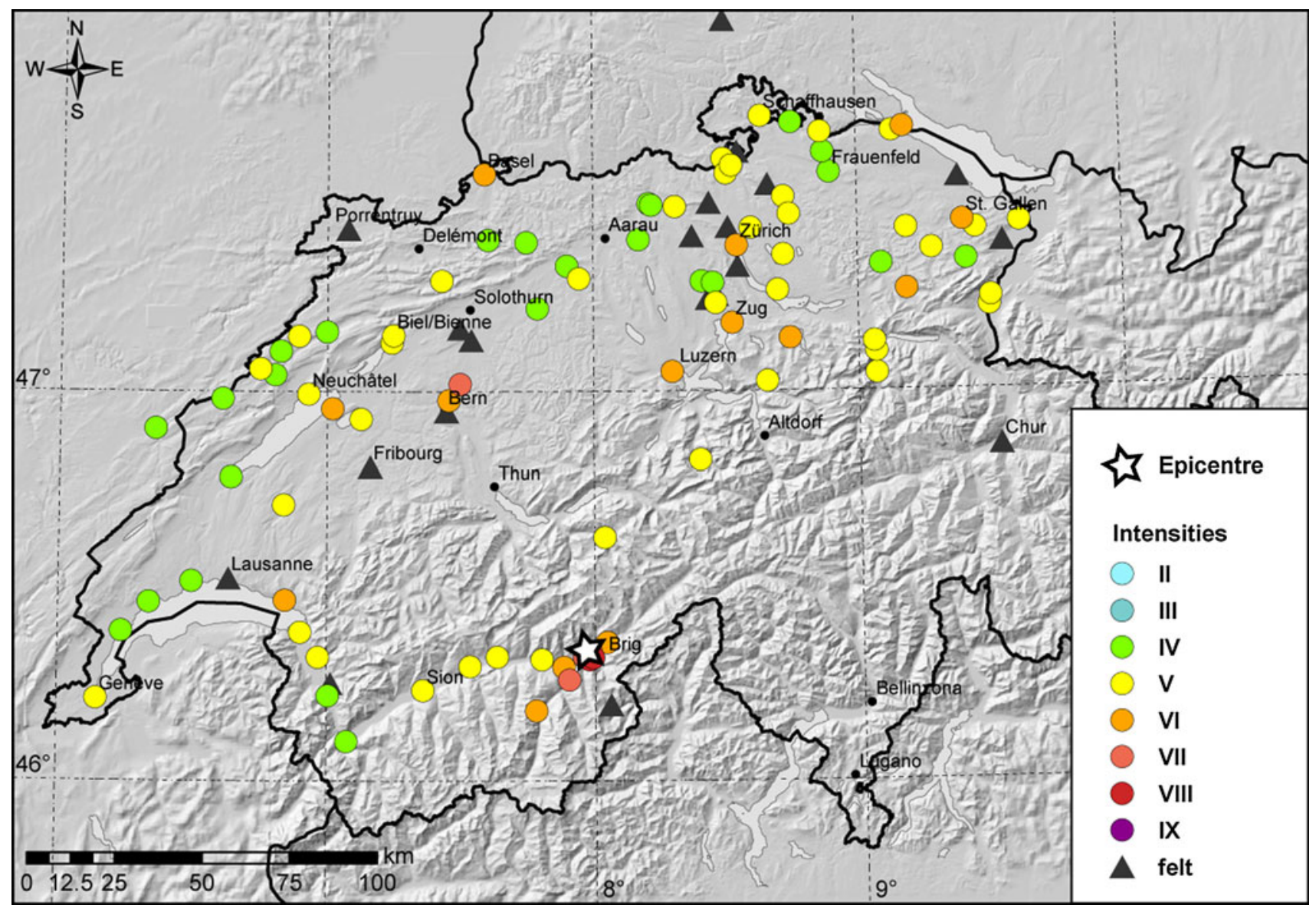

Fig. 3 Macroseismic field of the 1755 event near Brig

mentioned that the spiral staircase of an asylum could no longer be used after the earthquake. For the region of the Canton Valais, historic data is even sparser. A single historic source reports heavy damage (which is not further specified) at the church of Saint Maurice. According to this source, the loss arose partly due to a rock fall.

\subsubsection{Secondary effects}

Documented observations regarding secondary effects are also rare. Two observations however are of major importance. Most notable is a report on a rockslide that killed about 320 people and several hundred animals on March 14, 3 days after the main shock (Fig. 2). Several historical sources agree that the main shock triggered the rockslide near Tour d'Aï $(2,331 \mathrm{~m})$. For 3 days the material of the rockslide came to rest on a terrace about 1,200 $\mathrm{m}$ above sea level before it again started to move. It is supposed that an aftershock could have been responsible for this. The rockslide overwhelmed the two villages Corbeyrier and Yvorne almost completely and destroyed 69 houses, 126 barns and 5 mills in total. In a study, Albert Heim (1932) assessed this disaster as an event that had threatened the two villages for a long time. According to Heim, the earthquake series, in combination with snow and rainfall, was the only trigger.

Another well-documented phenomenon is a tsunami and seiche in Lake Geneva (Fig. 2). Reports exist for the region of the Rhone delta as well as for Lausanne and Geneva and give an account of flooded and damaged watersides (Villeneuve, Lausanne, Geneva) and the temporary draining of the Rhone river (Geneva). The reports agree with respect to observations of "stormy waters" on the lake. One observer describes the difference between high and low water levels with "more than five feet". An investigation of the Rhone delta in 1991 by Jean-Luc Loizeau discovered changes in the sediments that could originate from this flooding. Similar changes have been observed after the collapse of the quay in Montreux in 1891. Engineer Hans Schardt, assigned with the repair of the quay, found an old settling within the sediments, which he identified as one of the reason for the failure of the structure. Based on historic documents and a map, he brought the settling into connection with the earthquake of 1584 . 
Table 3 Summary of the 1855 event near Visp

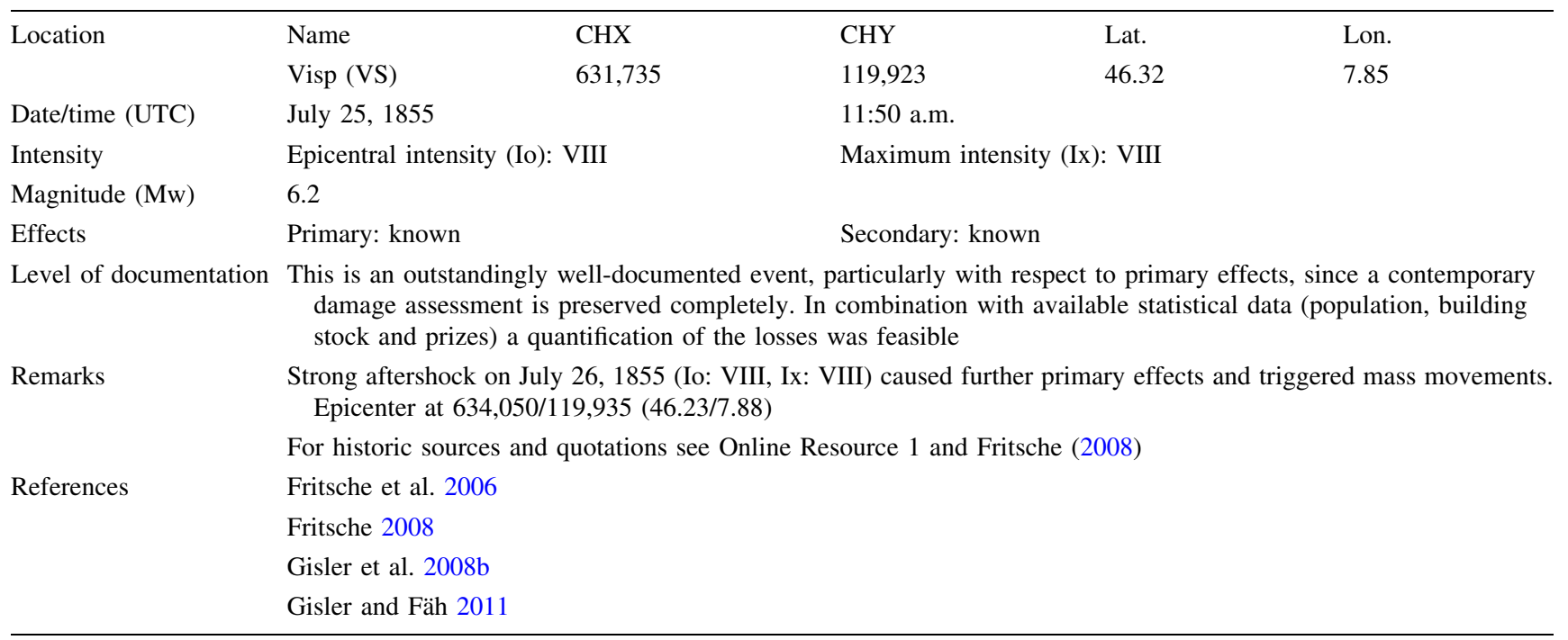

Location, date and time, intensity and magnitude are taken from ECOS-09 (Fäh et al. 2011a)

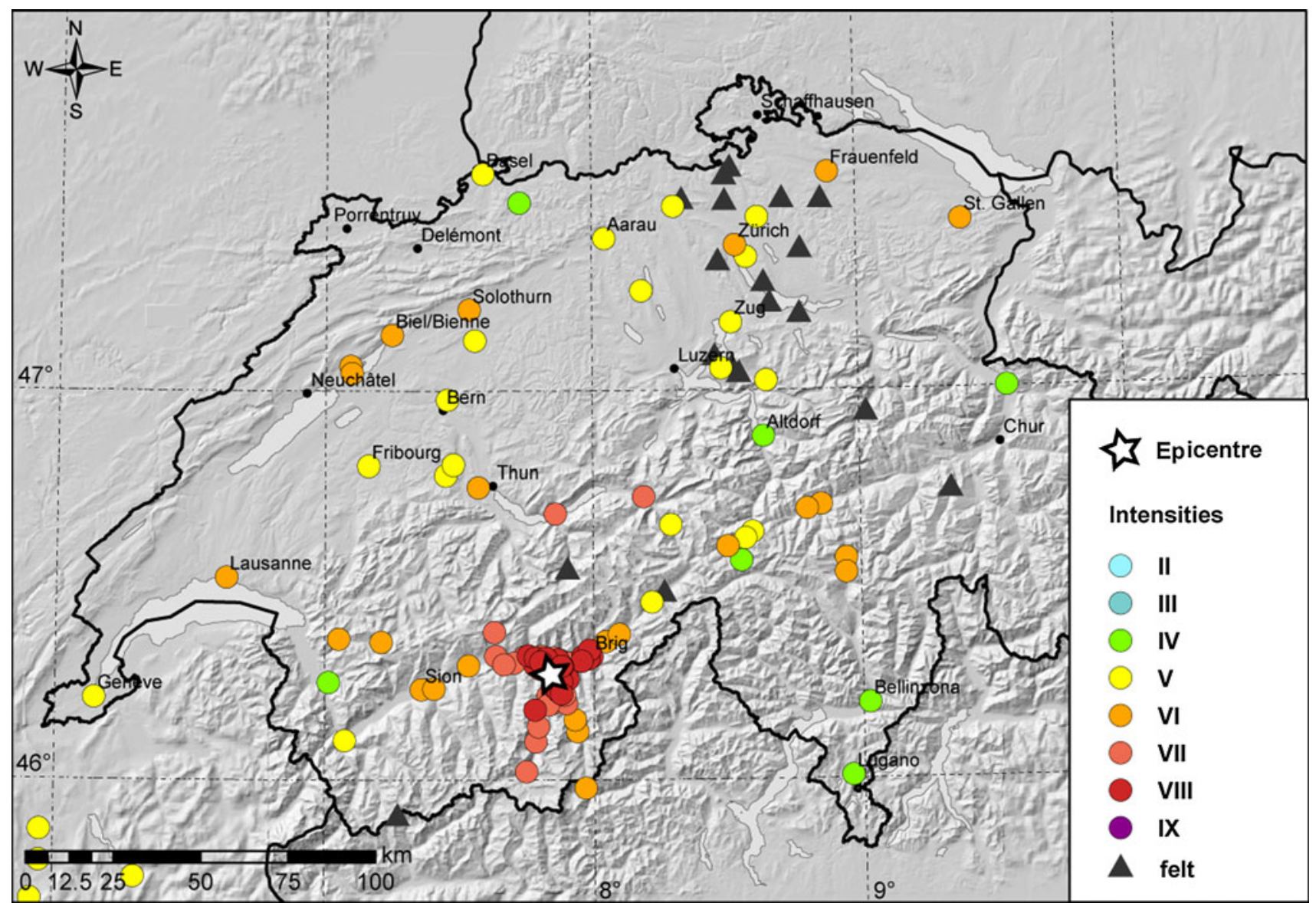

Fig. 4 Macroseismic field of the 1855 event near Visp 


\subsection{The 1755 event near Brig}

\subsubsection{Overview}

A few weeks after the disastrous event of Lisbon (November 1, 1755), the Valais region was struck by the strongest earthquake of the 18th century, with an epicenter near Brig in the upper Valais (Table 2; Fig. 3). Slight losses were reported up to distances of $400 \mathrm{~km}$. The earthquake was also felt in neighbouring countries on a belt around Switzerland of about $200 \mathrm{~km}$ in width. Due to the temporal proximity to the Lisbon event and since the latter was also observed in Switzerland, namely in terms of effects on lakes and rivers (Gisler et al. 2004), the seismic event was sometimes brought into correlation with the Lisbon earthquake by contemporary reports. This had consequences for the perception, reporting and interpretation of the Brig event. Contemporaries who experienced, or knew of, both earthquakes, often misinterpreted or confused these events. Thus, it is sometimes impossible to separate the observations. In some cases the Brig event was interpreted as an aftershock of the Lisbon earthquake (Gisler et al. 2004).

Historical reports documenting primary and secondary effects systematically are absent. The macroseismic field is thus based on a large number of individual documents of different types (Fig. 3). Similar to other events that occurred centuries ago, the 1755 earthquake showed that the quality and quantity of historical documents vary for different regions. In rural areas, such as the Valais region, written records and archival storage were less common than in urban centres. Moreover, it was usual that observers at this time concentrated more on important infrastructure, such as castles and churches due to their importance for the respective communities (Gisler et al. 2004).

\subsubsection{Primary effects}

The town of Brig probably suffered the most severe damage. According to several sources almost all buildings suffered loss in some way. Most of the walls had cracks of different extent, while a considerable number of buildings

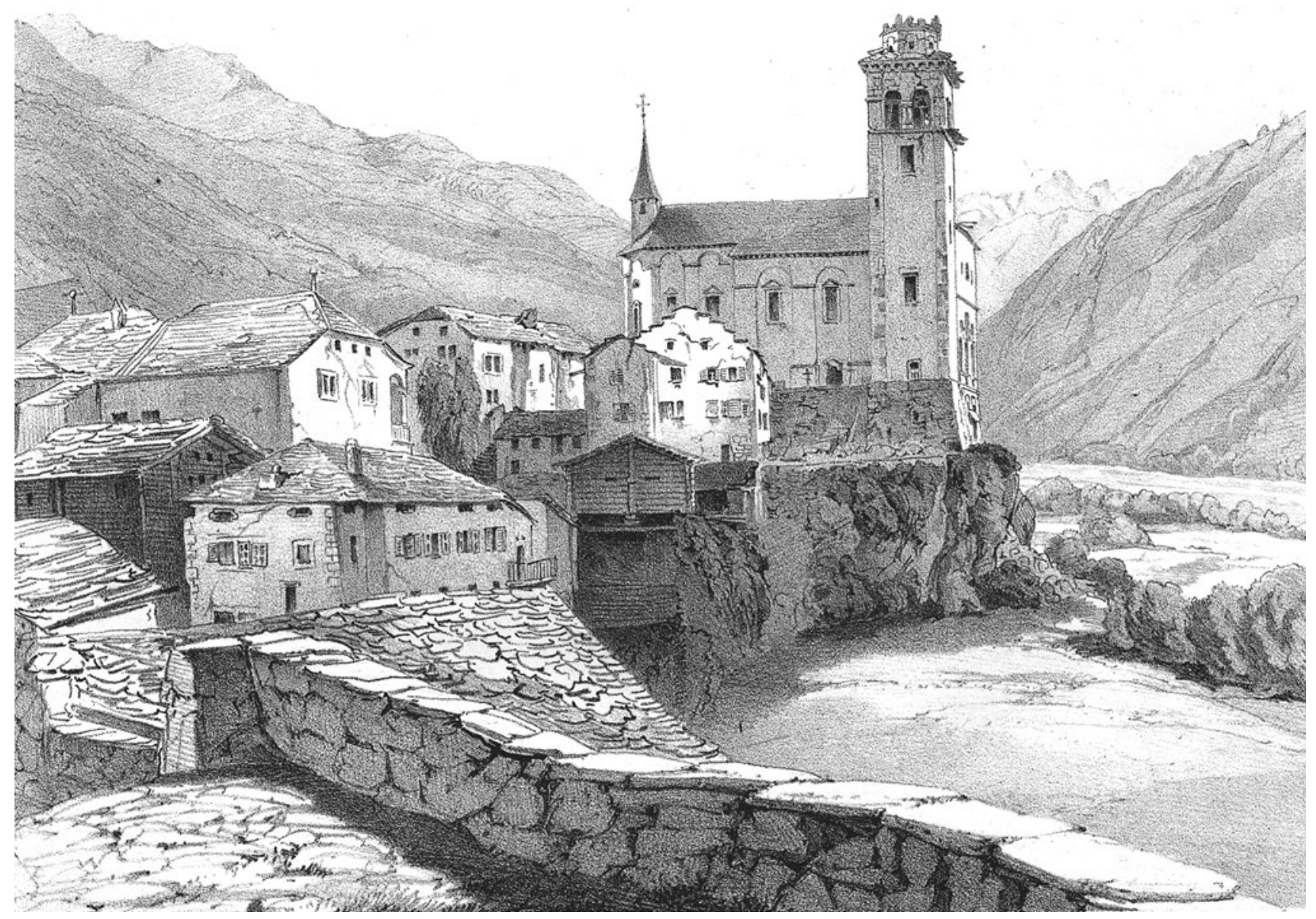

Fig. 5 Visp and the Martinskirche with the tower damaged by the 1855 event (Heusser 1856) 
partially collapsed. Collapsed chimneys were omnipresent. Several churches suffered damage, especially to their bell towers. The famous Stockalper-Palace sustained severe damage to its outer walls and the tower. Revision of the event's strength and magnitude by Gisler et al. (2004) assigned intensity VIII to Brig. In Glis, a village in the immediate vicinity of Brig, the intensity was comparable. An observer rated the damage as even more serious as in Brig. Parts of the bell tower collapsed and it took several months before the church could be used again. A chapel on the top floor of a building was also completely destroyed. The partial destruction of well-built buildings, such as the previously mentioned Stockalper-Palace and others in these two villages, implies that probably many other (weak) buildings or constructions in bad conditions sustained severe damage, even if they are not mentioned in the reports.

For Mund, located about $4 \mathrm{~km}$ to the west of the epicenter, it is known that the church was seriously damaged.
The rafters of the bell tower collapsed and destroyed parts of the church. Gisler et al. (2004) assigned intensity VII to this village. For Visp, where 14 chimneys collapsed and the bell tower of the church suffered damage to its gallery, intensity assignment ranges from VI to VII. In Mörel, a rectory collapsed partly due to the failure of a wall, while in St. Niklaus parts of a chapel collapsed. For Valaisan villages farther from the epicenter, such as Sion, Sierre, Leuk and others, no damage was reported. Yet, the earthquake was widely observed and damage occurred also outside the Canton of Valais, and at larger distances, such as in Neuchâtel, in Cudrefin (on the shores of Lake Neuchâtel), and in Bern. The most likely intensity for these sites is VI (Gisler et al. 2004).

\subsubsection{Secondary effect}

Reports of secondary phenomena in the epicentral region are rare for the 1755 earthquake (Gisler et al. 2004). Most of

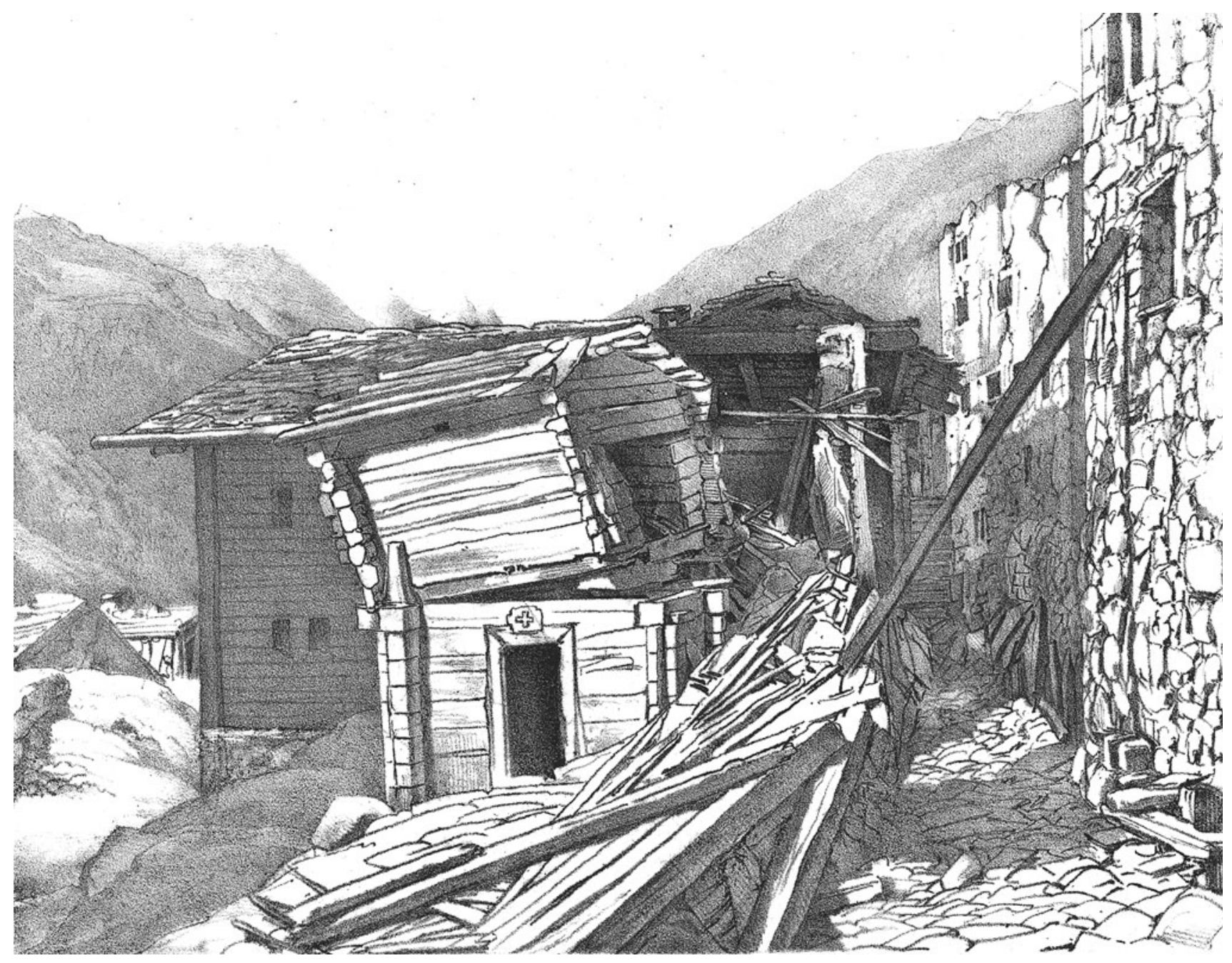

Fig. 6 St. Niklaus, near Visp, after the main shock of July 25, 1855 (Heusser 1856) 
the observations report about rather weak effects, such as fissures and cracks in the ground, as well as springs that started to flow in and around Brig (Gisler et al. 2004). Regarding mass movements, all we know is that the earthquake triggered a single slight earth slump in the immediate vicinity of Brig. A recent study revealed that a large rockslide, with an approximate volume of $\sim 1.5$ million $\mathrm{m}^{3}$, might have been triggered on the Durlochhorn. This destroyed parts of the village of Niedergrächen above the Matter valley (Heynen 2010).

Other secondary effects have been observed in the western part of Switzerland (Biel, Murten) and in northeastern Switzerland (from Zurich to St. Gallen). Most of them are related to changes in the water level in lakes or outflow in springs. For Lichtensteig, a case of gas emission was reported and a small landslide occurred near St. Gallen (Gisler et al. 2004).

When compared with the 1855 event in the Visp region, the number of observations of secondary effects is low in the epicentral region, particularly in the category of mass movements. It remains an open question, whether the 1755 event triggered fewer landslides and rock falls or whether observations did not enter written records. Moreover, in 1855 a number of scientists visited the epicentral region with obvious interest in secondary effects. Their reports describe and quantify many different cases of mass movements triggered by an earthquake of similar intensity.

\subsection{The 1855 event at Visp}

\subsubsection{Overview}

The Visp earthquake of 1855 remains the strongest of the last 300 years in Switzerland (Table 3). It caused heavy damage in the region of the middle Valais. It was felt up to distances of more than $200 \mathrm{~km}$ (Fig. 4). Investigations of this event benefited significantly from the fact that the 1855 event is unusually well documented. Given the existence of a

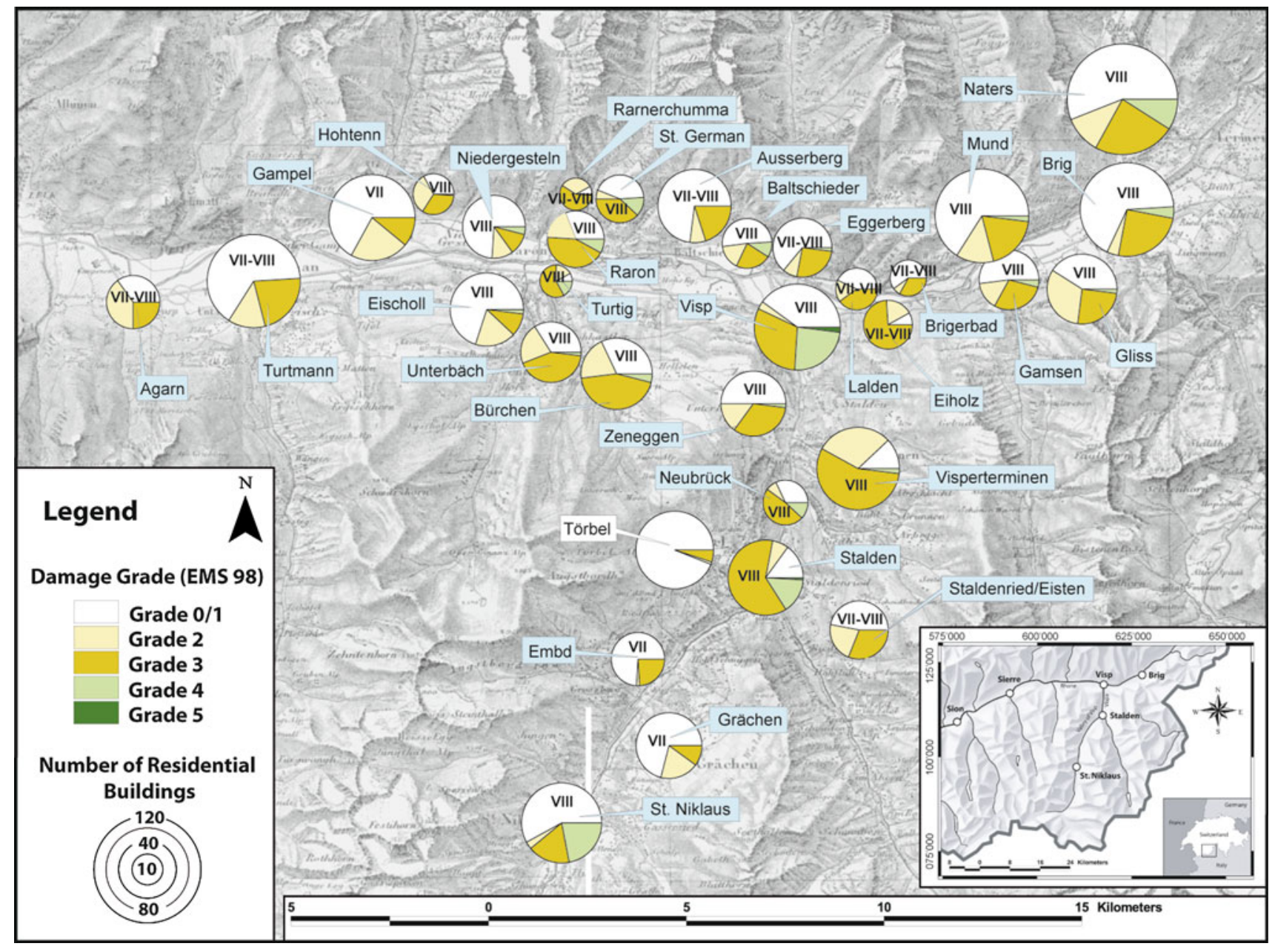

Fig. 7 Damage grades and intensities assigned on the basis of the contemporary damage assessment for the 1855 event. For locations with intensity degrees in the form of VII-VIII, it is unclear which value is appropriate. They contain elements of intensity degrees VII and VIII. Redrawn from Fritsche et al. (2006) 
complete contemporary damage assessment and the availability of early statistics, the investigation drew upon an excellent pool of data (Online Resource 1, Fritsche et al. 2006). This offered the opportunity to quantitatively analyze the damage field at the village-level using the statistical features of the European Macroseismic Scale (EMS 98, Grünthal 1998). Further historical sources, in particular a few travel dairies of scientists visiting the region after the earthquake, provide valuable descriptions regarding secondary effects (e.g. Nöggerath 1855; Volger 1856; Heusser 1856).

\subsubsection{Primary effects}

The 1855 event reached an intensity of VIII (Io) in the epicentral region (Fig. 7). In many villages near the epicenter $50 \%$ or more of the existing buildings suffered severe damage. The villages of Visp (Fig. 5), St. Niklaus (Fig. 6), Stalden and Naters are the most notable, where damage of grade 4 was frequent and damage of grade 3 omnipresent (see Fig. 7; Table 4 for examples of the original damage assessment and its interpretation). A case study for the village of Visp showed that site effects had only a minor impact on the damage distribution (Fig. 8). This is a surprising result, since parts of Visp are built on thick alluvial sediments that potentially amplify ground shaking. An explanation for this finding is the close proximity of the fault of the earthquake: source and directivity effects probably superposed site effects. For Naters, which shows comparable ground condition, detailed studies are absent so far.

Table 4 Extracts of the damage assessment and interpretation for the 1855 event near Visp (see Online Resource 1) (StAW, DI, 27.3.3)

\begin{tabular}{|c|c|c|c|c|}
\hline Village & Damage description (original) & Paraphrase & $\mathrm{CHF}$ & Damage grade (EMS98) \\
\hline Eyholz & $\begin{array}{l}\text { 005. A Pierre Joseph Naepfli, pour } \\
\text { réparer le toit d'une grange }\end{array}$ & $\begin{array}{l}\text { For Pierre Joseph Naepli, for repairs on } \\
\text { the roof of a barn }\end{array}$ & 5 & \multirow{3}{*}{$\begin{array}{l}\text { Grade 2: Moderate damage (slight } \\
\text { structural damage, moderate non- } \\
\text { structural damage) } \\
\text { Cracks in many walls. Fairly large } \\
\text { pieces of plaster fallen. Partial } \\
\text { collapse of chimneys }\end{array}$} \\
\hline Agarn & $\begin{array}{l}\text { 027. Meyer, Jean, reboucher les fentes } \\
\text { dans la cheminée et un mur }\end{array}$ & $\begin{array}{l}\text { Meyer, Jean, to fill the fissures in the } \\
\text { chimney and in a wall }\end{array}$ & 6 & \\
\hline Glis & $\begin{array}{l}\text { 028. Dans la maison de François } \\
\text { Nanzer, une petite partie du mur de } \\
\text { la maison à réparer }\end{array}$ & $\begin{array}{l}\text { In the house of Fronaçois Nanzer, a } \\
\text { small part of a wall has to be } \\
\text { repaired }\end{array}$ & 10 & \\
\hline Eyholz & $\begin{array}{l}\text { 011. A Pierre Heinzmann pour faire } \\
\text { une nouvelle cheminée et réparer le } \\
\text { toit de la maison }\end{array}$ & $\begin{array}{l}\text { For Pierre Heinzmann to build a new } \\
\text { chimney and for repairs on the roof }\end{array}$ & 35 & $\begin{array}{l}\text { Grade 3: Substantial to heavy damage } \\
\text { (moderate structural damage, heavy } \\
\text { non structural damage) }\end{array}$ \\
\hline Brig & $\begin{array}{l}\text { 026. A Loretan, pour sa maison, y } \\
\text { refaire } 2 \text { cheminées, réparer le toit, } 2 \\
\text { plafonds, latrines, etc. }\end{array}$ & $\begin{array}{l}\text { For Loretan, for a new chimney, to fix } \\
\text { the roof, two ceilings and the latrine, } \\
\text { etc. }\end{array}$ & 60 & \multirow{2}{*}{$\begin{array}{l}\text { Large and extensive cracks in most } \\
\text { walls. Roof tiles detached. Chimneys } \\
\text { fractured at the roofline; failure of } \\
\text { individual nonstructural elements } \\
\text { (partitions, gable walls) }\end{array}$} \\
\hline Visp & $\begin{array}{l}\text { 007. Pfamatter, François, a réparer le } \\
\text { toit, } 1 \text { cheminée neuve, plusieurs } \\
\text { fentes dans la maison, le toit et } 4 \\
\text { toises de mur à la grange }\end{array}$ & $\begin{array}{l}\text { Pfammatter, François. For repairs of } \\
\text { the roof, for a new chimney, to fix } \\
\text { several cracks in the house and for } \\
\text { four fathoms of wall at the barn }\end{array}$ & 191 & \\
\hline Baltschieder & $\begin{array}{l}\text { 003. Nellen, Jean Joseph boulanger, } \\
\text { refaire vingt toises de mure et } \\
\text { terrasse, deux clefs, deux toits et } \\
\text { plusieurs crevasses }\end{array}$ & $\begin{array}{l}\text { Nellen Jean Josef, baker. Rebuilding } 20 \\
\text { fathoms of wall and terrace, repairs } \\
\text { on two con rods, two roofs and } \\
\text { several cracks }\end{array}$ & 400 & \multirow{3}{*}{$\begin{array}{l}\text { Grade 4: Very heavy damage (heavy } \\
\text { structural damage, very heavy non- } \\
\text { structural damage) } \\
\text { Serious failure of walls; partial } \\
\text { structural failure of roofs and floors }\end{array}$} \\
\hline Naters & $\begin{array}{l}\text { 004. Michlig, Thérèse, réparer le } \\
\text { couvert, les cheminées et remonter } 2 \\
\text { murs de façade et plusieurs terrasses, } \\
\text { inhabitable }\end{array}$ & $\begin{array}{l}\text { Michlig, Thérèse, repairs on the roof, } \\
\text { the chimneys and reconstruction of } \\
\text { two walls of the facade and several } \\
\text { terraces, uninhabitable }\end{array}$ & 975 & \\
\hline Visp & $\begin{array}{l}\text { 009. Eder, Zumstein, Jos. et Imboden, } \\
\text { Maurice, dans la maison: la façade } \\
\text { du midi, les deux angles du couchant } \\
\text { et une partie de la façade du nord }\end{array}$ & $\begin{array}{l}\text { Eder, Zumstein, Jos. and Imboden, } \\
\text { Maurice, on the house: the facade to } \\
\text { the south, the two corners to the west } \\
\text { and a part of the northern facade }\end{array}$ & 9,400 & \\
\hline Stalden & $\begin{array}{l}\text { 001. Kalbermatten, Pierre et Venetz, } \\
\text { Anne Marie et Venetz, Joseph } \\
\text { Ignace, maison écroulée remonter à } \\
\text { neuf }\end{array}$ & $\begin{array}{l}\text { Kalbermatten, Pierre et Venetz, Anne } \\
\text { Marie et Venetz, Joseph Ignace. The } \\
\text { house collapsed, to rebuild }\end{array}$ & 3,600 & \multirow[t]{3}{*}{$\begin{array}{l}\text { Grade 5: Destruction (very heavy } \\
\quad \text { structural damage) } \\
\text { Total of near total collapse }\end{array}$} \\
\hline Visp & $\begin{array}{l}\text { 081. Andenmatten, notaire et } \\
\text { Gentinelly, Laurent, démolir tout la } \\
\text { maison et rebâtir à neuf }\end{array}$ & $\begin{array}{l}\text { Andenmatten, notary et Gentinelly, } \\
\text { Laurent, the whole house has to be } \\
\text { demolished and rebuilt }\end{array}$ & 7,800 & \\
\hline Visp & $\begin{array}{l}\text { 078. Stauffer, Ant. et Schaller Ant., } \\
\text { maison écroulée, rebâtir à neuf }\end{array}$ & $\begin{array}{l}\text { Stauffer, Ant. Et Schaller Ant., the } \\
\text { house has collapsed, rebuilding the } \\
\text { house }\end{array}$ & 10,000 & \\
\hline
\end{tabular}


Fig. 8 Building damage and secondary phenomena in and around the village of Visp after the 1855 event. Comparison of loss on buildings built on rock and soft soil shows no significant differences. Strong secondary phenomena occurred particularly in the northern part of Visp. Modified from Fritsche et al. (2006)

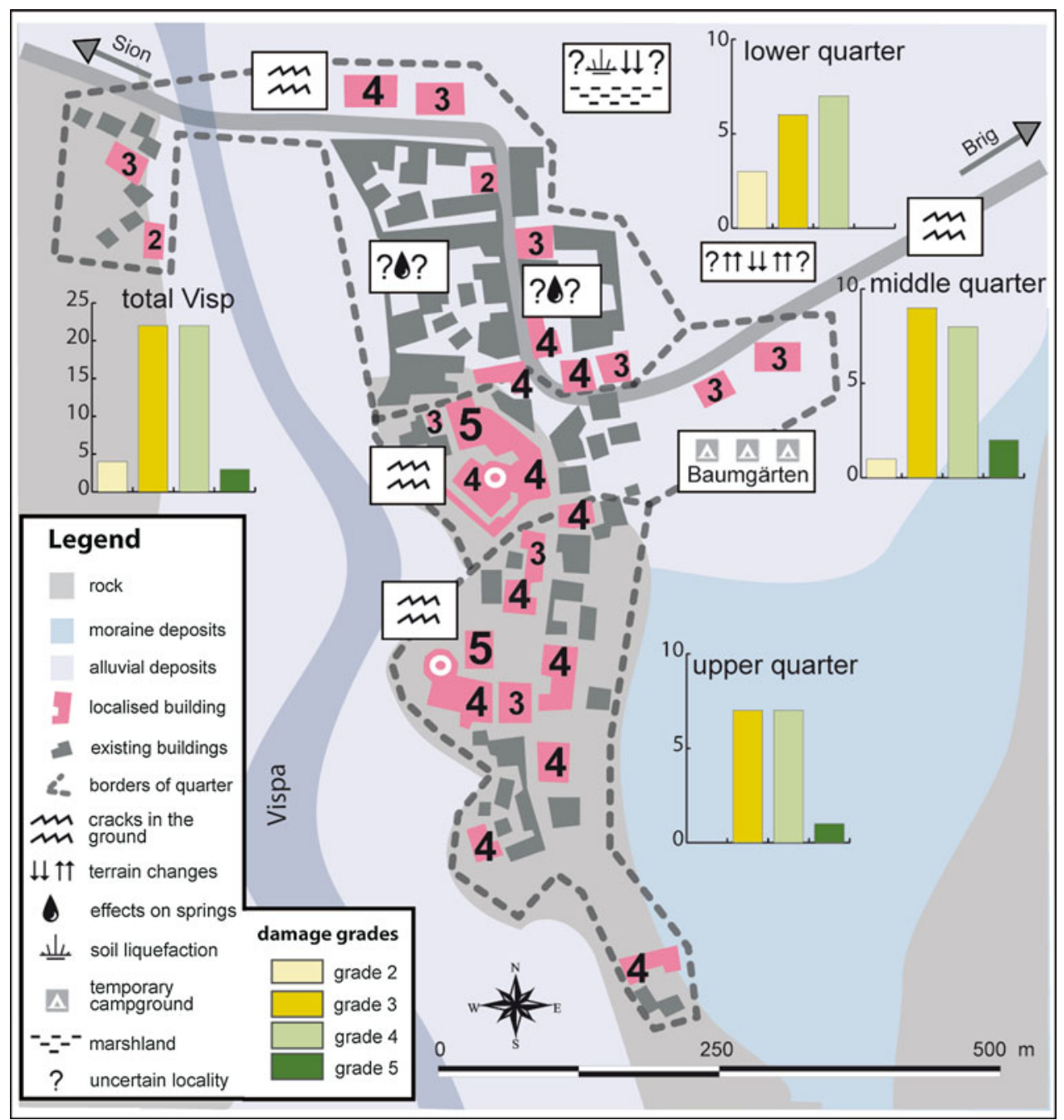

The damage assessment performed after the earthquake completely covered the epicentral region. In the 19th century the region included about 30 villages with 11,000 citizens, encompassing an area of about $400 \mathrm{~km}^{2}$. In the assessment 1,800 cases of loss could be identified, of these, approximately 1,000 were residential buildings. Repair costs then totalled CHF 530,000.00 (StAW, DI, 27.3.3., Fritsche et al. 2006). In order to offer a comparison, the income of a person at this time was usually well below CHF 1.00 per day. According to the investigated sources only one person was killed due to the earthquake. Little is known about injured persons, but the number is probably also low since the earthquake occurred in the summertime and during the day, when most people were working in the fields. The same region at present has a population of about 43,000 , and a similar earthquake today would certainly cause greater loss of life as well as damage measured in billions of Swiss francs.

\subsubsection{Secondary effects}

The number of secondary effects specified in historical documents is large for the 1855 event. Particularly important are the above mentioned travelogues of a few scientists visiting the region after the earthquake (Online Resource 1). In these travelogues they describe diverse observations from Visp and its surrounding region, and up along the Matter Valley towards Zermatt. Other parts of the epicentral region were ignored. This explains, for example, the lack of observations in the Saas Valley to the east (Fig. 9). Generally frequent are observations of mass movements, such as rock falls and landslides. Of particular interest is a landslide below Grächen and a rock fall that threatened the village of St. Niklaus. The former was of considerable extent, the latter apparently a serious danger for the village (Online Resource 1). Beside these two events, a considerable number of smaller (or less precisely 
Fig. 9 Seismo-geological effects in the Visp region and Matter valley caused by the 1855 event. Redrawn from Fritsche et al. (2006)

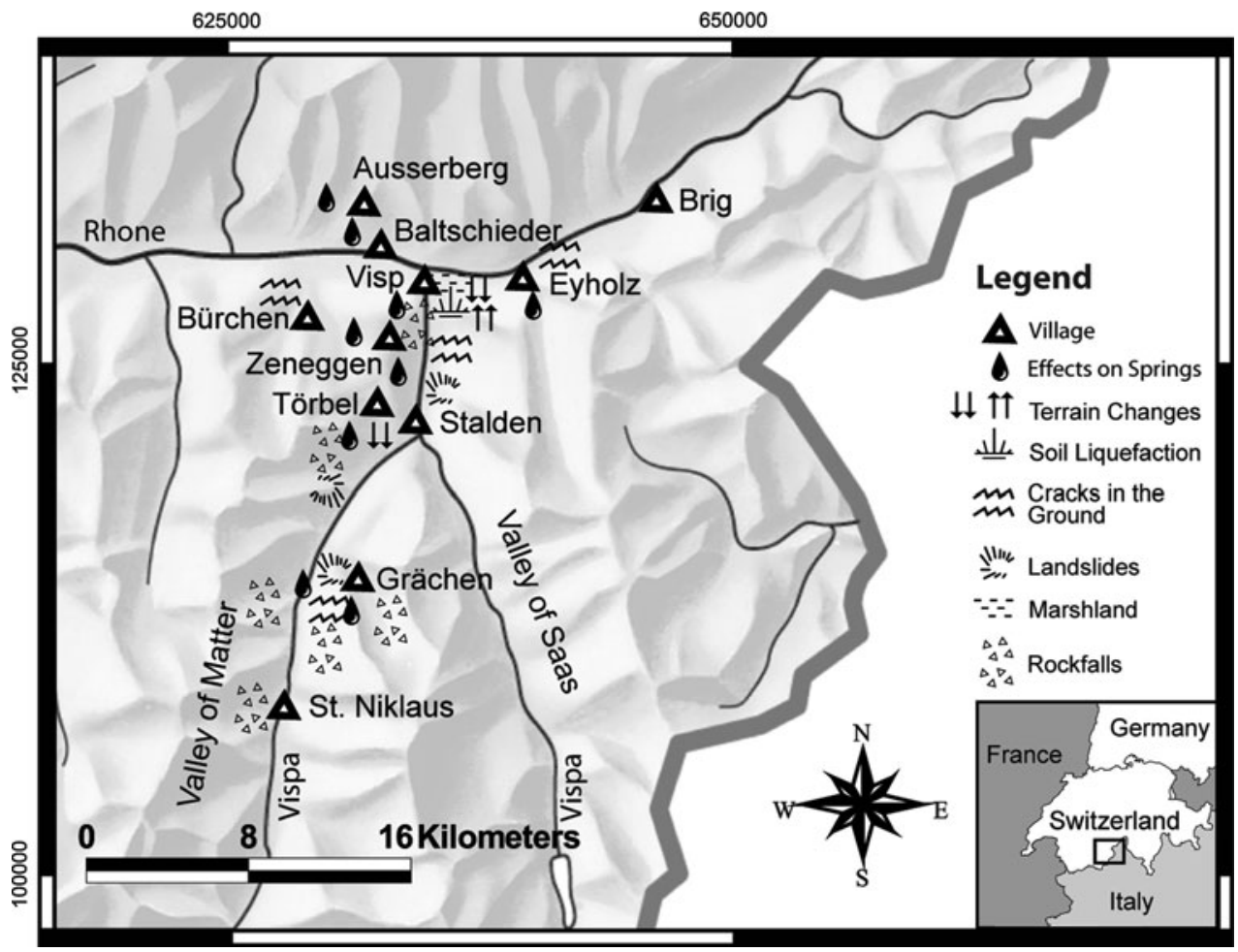

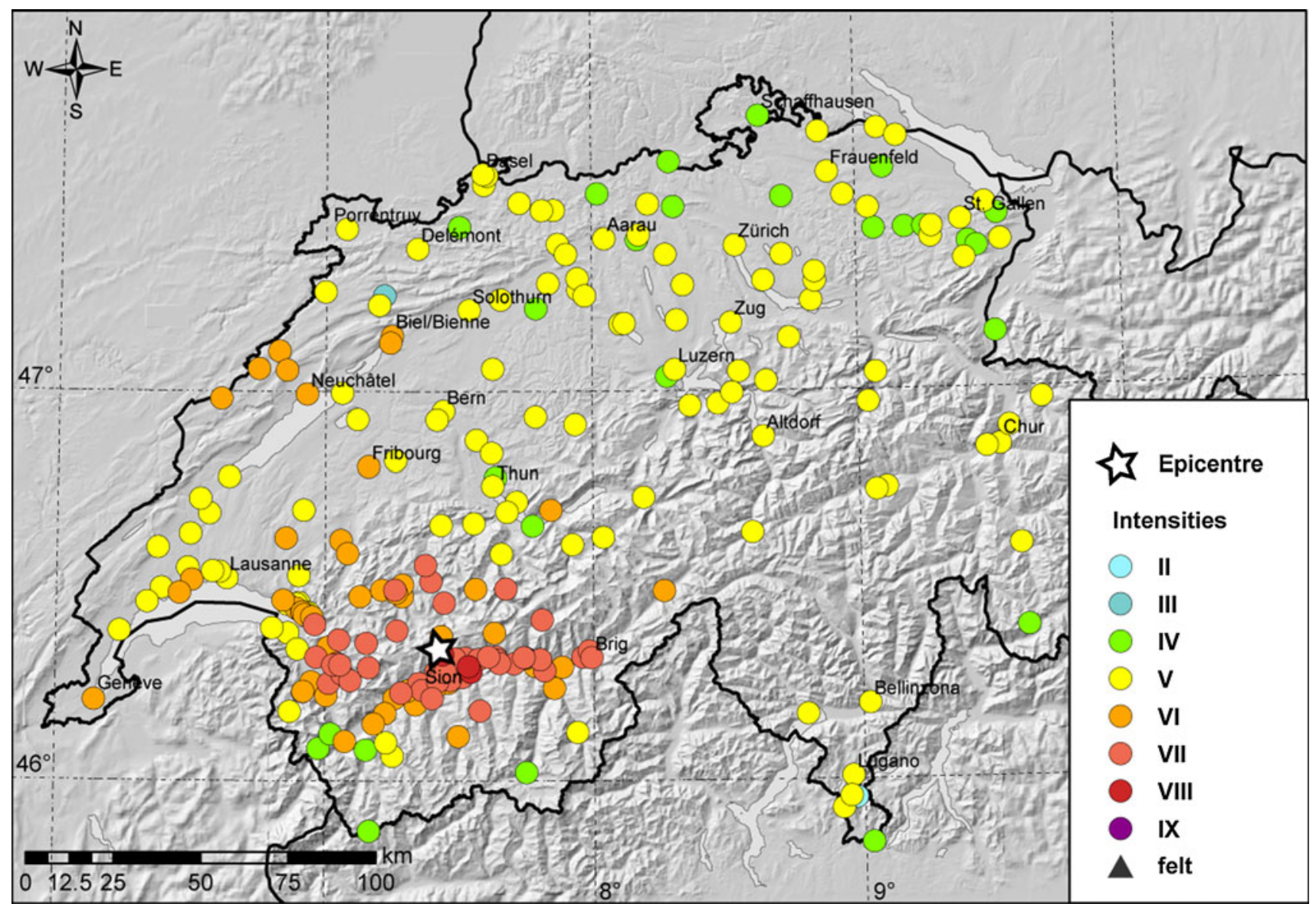

Fig. 10 Macroseismic field of the January 25, 1946 event near Sierre (main shock) 
documented) mass movements are documented (Fig. 9 and Online Resource 1). However, other types of secondary effects were also recognized (Fig. 9). A plausible historical document mentions ground deformation in the northern part of Visp that can be associated to lateral spreading of liquefied soils (Nöggerath 1855). Another source describes a phenomenon that we interpret as widespread settlement due to ground liquefaction (Conseil d'État 1859). Finally, effects on springs and cracks in the ground have been observed in the whole epicentral region. Unfortunately, for

Table 5 Summary of the 1946 event near Sierre

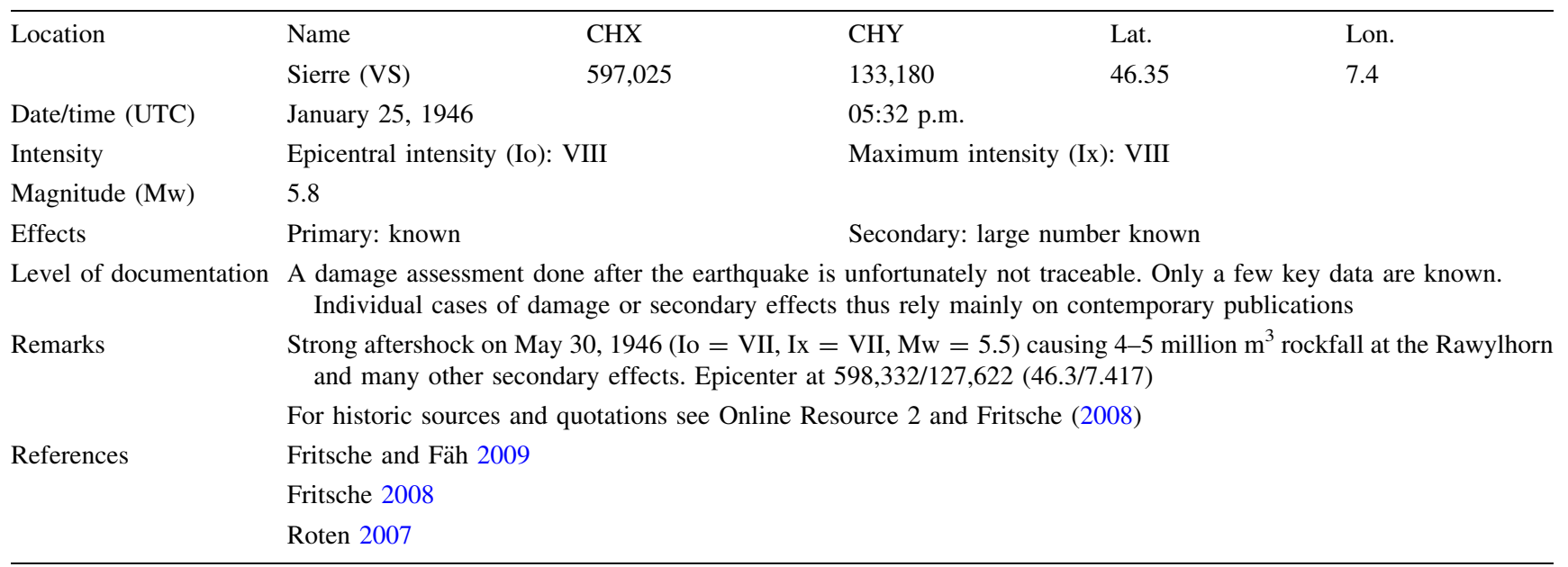

Location, date and time, intensity and magnitude are taken from ECOS-09 (Fäh et al. 2011a)

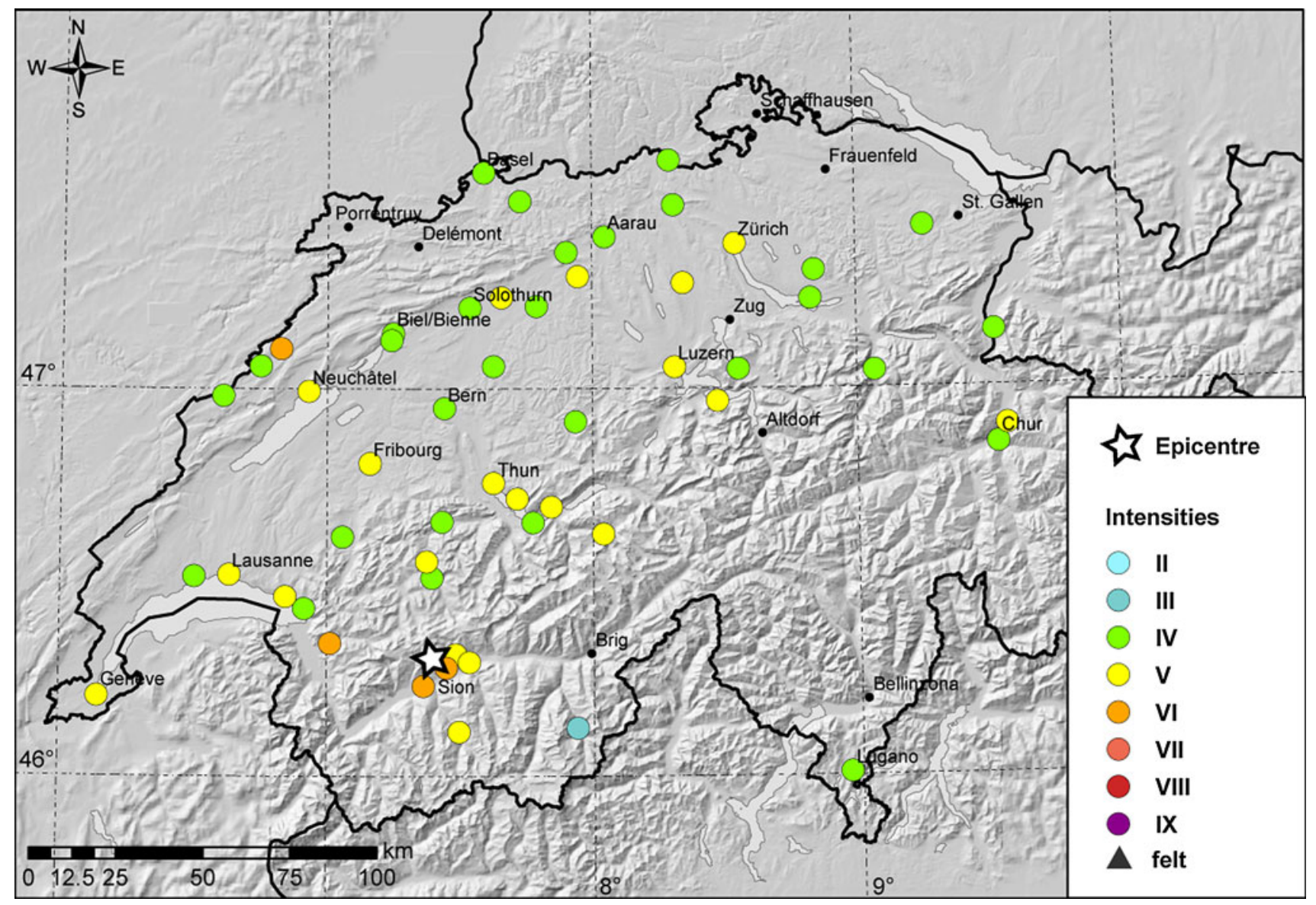

Fig. 11 Macroseismic field of the May 30, 1946 event near Sierre (aftershock) 
many of the minor observations it was not possible to identify their exact locality.

\subsection{The 1946 event at Sierre}

\subsubsection{Overview}

The January 25, 1946 earthquake in the Central Valais region in the southwest of Switzerland was the strongest in Switzerland since the 1855 Visp event. It reached an epicentral intensity $\mathrm{Io}=\mathrm{VIII}$ in the Sion-Sierre region (Fig. 10; Table 5) and a magnitude of $\mathrm{Mw}=5.8$. The earthquake caused moderate to high damage within a radius of about $25 \mathrm{~km}$. Slight damage occurred up to a distance of $200 \mathrm{~km}$ from the epicenter. Although several thousand people were exposed to intensity VIII, severe injury to persons was rare. Three persons died of shock, a fourth was crushed by a car.

A strong aftershock on May 30, 1946 (I = VII, $\mathrm{Mw}=5.5$ ) triggered a large rockslide of several million cubic meters at the Rawylhorn (Figs. 11, 12). Similar to the 1855 event, this earthquake was investigated to understand whether site effects had an impact on the damage distribution (Fritsche 2008). Although the earthquake occurred only six decades ago, the available data regarding primary effects are not as good as for the 1855 event. Unfortunately a contemporary damage assessment, done on behalf of the Canton Valais has survived in fragments only. Thus, quantitative investigations were merely practicable on the district level. Secondary effects are rather well documented, in particular due to a large number of newspaper articles.

\subsubsection{Primary effects}

Considering only major damages, the loss of building infrastructure amounted to CHF 5.3 million. That is equivalent to about CHF 25 million today (Bundesamt für Statistik). Approximately 3,500 of 22,000 buildings in Canton Valais sustained damage. In general the results

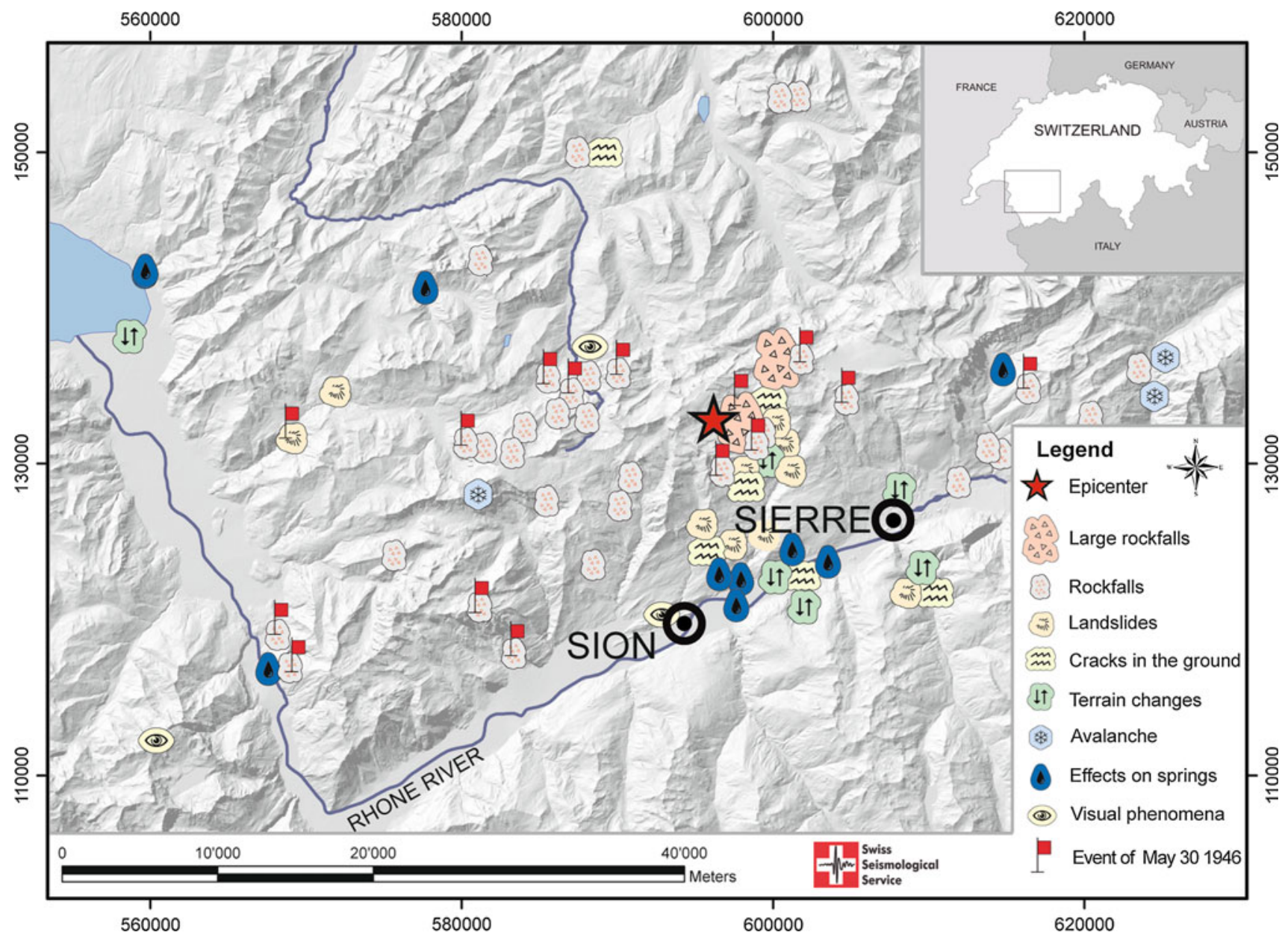

Fig. 12 Seismo-geological effects observed in the Valais and the neighbouring Cantons after the 1946 events. The figure includes effects, which occurred during the main shock and as consequence of the aftershock of May 30, 1946 (marked by flags). Taken from Fritsche and Fäh (2009) 


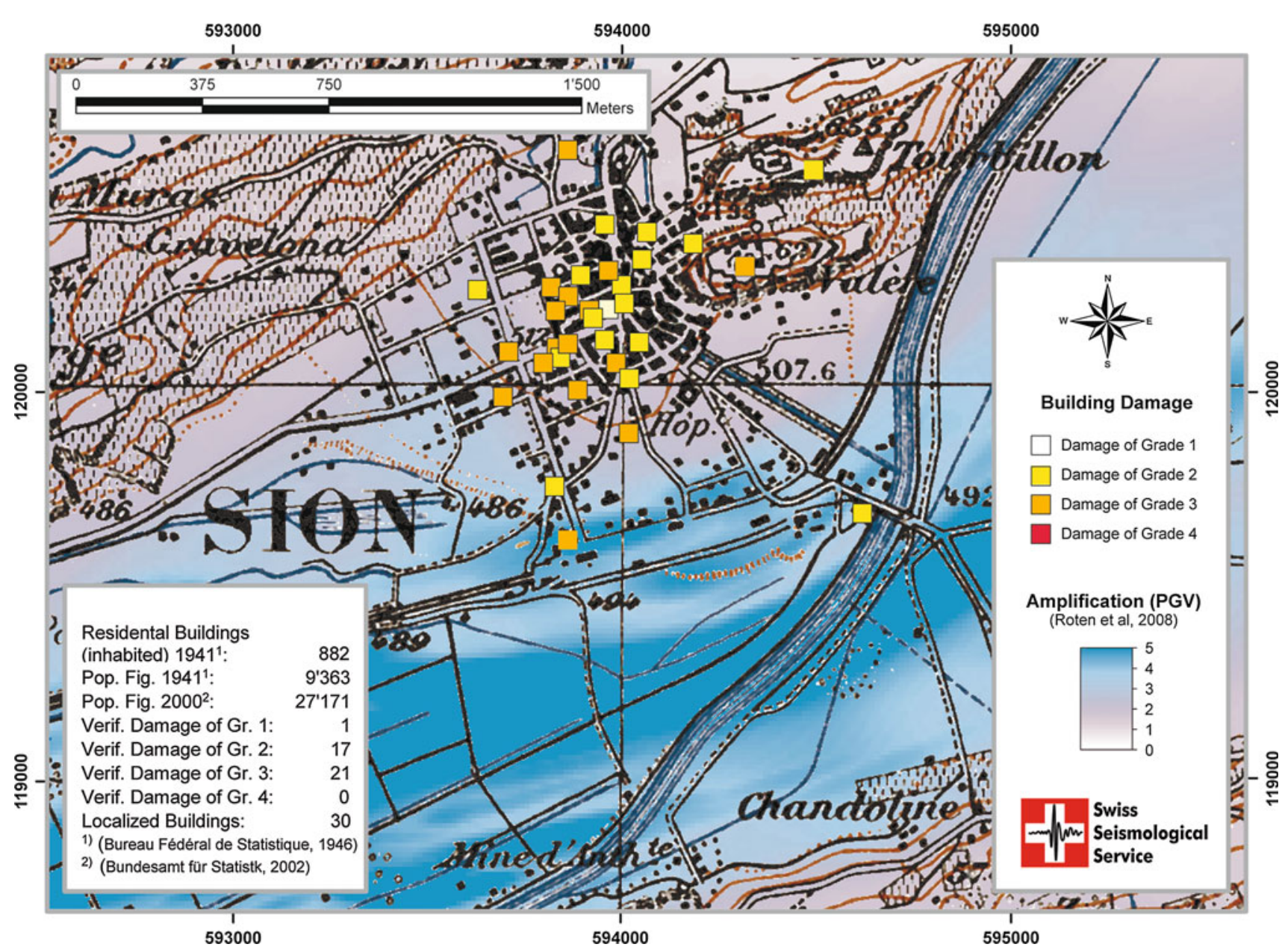

Fig. 13 Localized damage at Sion after the 1946 events and expected amplification on the floor of the Rhone Valley from numerical simulations (Roten et al. 2008). Taken from Fritsche and Fäh (2009)

show that damage in districts with a high percentage of infrastructure on the lacustrine and fluviatile deposits of the Rhone valley floor show higher loss than other districts (Fritsche and Fäh 2009). Regarding the cities of Sierre and Sion, two case studies led to more detailed results. Sion is located on compacted sediments with relatively high shearwave velocities (Roten 2007). The city suffered only moderate damage, rather regularly distributed (Fig. 13). In Sierre, on the other hand, two zones of significantly increased damage were identified, in which site-effects appear to be a very probable contributor to the observed damage. Local two- or three-dimensional resonance phenomena played an important role in this feature (Fig. 14).

\subsubsection{Secondary effects}

A large number of secondary effects are documented in contemporary publications (most notably newspaper and journal articles, see Online Resource 2 for examples). In total we could identify about 90 events, and among them several dozen landslides (Fig. 12 and Online Resource 2). Less frequent are reports about effects on springs, cracks in the ground, terrain changes and avalanches. It is evident in this context that 25 observations are related to the aftershock of May 30, 1946. Among the events released by this strongest aftershock is the voluminous rock fall from the Rawylhorn. This mass movement of 4-5 million cubic meters (Wanner and Grütter 1950) overwhelmed a small lake and a mountain pasture. Another large rock fall was triggered by the main event of January 25, 1946. Although smaller in volume when compared with the event of May 30 , it destroyed some mountain huts and pastures, and parts of a forest.

\section{Discussion and conclusions}

We know of three earthquakes that reached an intensity of VIII in the Valais region since the beginning of the 18th century, namely the Brig event in 1755, the Visp 


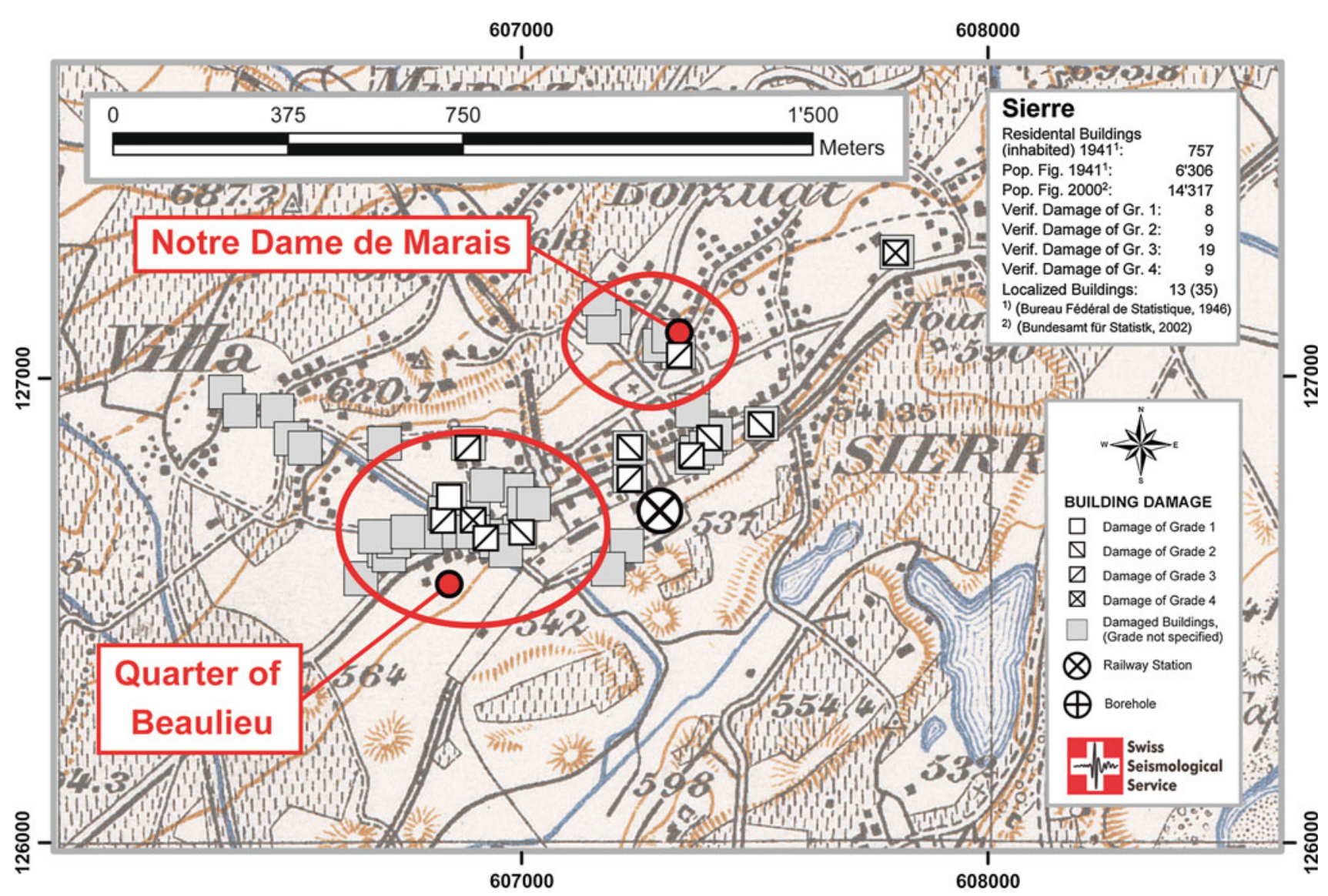

Fig. 14 Localized damage at Sierre after the 1946 event. The village shows two areas with increased damage density (quarters of Beaulieu and Notre Dame de Marais). The soil conditions on these sites make amplification effects likely. Modified from Fritsche and Fäh (2009)

earthquake in 1855 and the Sierre event in 1946. We assume that our list for this size of earthquakes is complete for this period. For the earlier centuries, historical information for earthquakes of similar magnitude exists for events in 1524 and 1584. Incompleteness of the record is attributed to less literacy for the period before 1700 , and it is likely that such earthquakes were not reported for the Valais region in some time periods, in particular before 1500 (Schwarz-Zanetti 2008b). Considering the period when the known events occurred, we infer, that the Valais region has been struck by an intensity VIII event (around $\mathrm{Mw}=6$ ) about every 100 years for the last half millennium. This sequence is superposed by magnitude 5 events about every 40 years. Due to the uncertainties given by the use of macroseismic methodologies applied on past events, these earthquakes occurred on faults, which are so far unidentified.

The number of events shows impressively that the region faces considerable seismic hazard and risk. For centuries the Valais remained a sparsely populated and poor region. Industrialization started late and slowly while agricultural development was limited due to the natural topography. In the 1850s, the Canton of Valais had a population of only about 80,000 , but 150 years later this number has increased to more than 270,000. A major cause for this strong growth was the regulation of the river Rhone (1863-1893 and 1930-1960). Prior to this, most of the valley floor could not be used because of recurring flooding. Nowadays, the Valais is a lively developing region with a growing commercial and industrial sector including an important tourism industry. Topography made the Valais region a key producer of hydroelectricity over the last century ( $\sim 30 \%$ of the national production).

Along with this economic/population growth, the infrastructure of the region has increased significantly. Residential and commercial buildings, factories, transportation lines, dams etc., were built and multiplied the existing building inventory over the last century. Even though the effort of the cantonal administration of Valais to prevent seismic impact is serious, the seismic risk remains high. The Swiss national building code (SIA 261) is obligatory since 2004, but most constructions were built before, in a period without obligatory earthquake regulations. Furthermore a large portion of this infrastructural growth took place on the valley floor. Empirical and theoretical investigations have shown that the ground of this 
area, consisting of thick sedimentary soils, behaves disadvantageously during earthquakes, when compared with the valley slope. Moreover important infrastructure is located below instable rock and soil slopes that might be triggered by strong earthquakes. In 1855 and even in 1946 most of the infrastructure was still situated on the valley slope, and as much as possible away from instable landslide areas. Nevertheless we could show that damage was more frequent and more severe on the valley floor due to site effects (amplification and elongation of the seismic signal) and nonlinear effects (liquefaction). At present the valley floor is partially to completely covered with infrastructure of different type, and important infrastructure is established in the smaller valleys of the tributaries of the Rhone. Estimation of possible earthquake impacts in the Valais is a scientific challenge that is currently being addressed by the COGEAR project (Coupled Seismogenic Geohazards in Alpine Regions, http://cogear.ethz.ch; Fäh et al. 2011b).

Due to the seismic hazard of the Valais region it is important to continue historic investigation. The next step has to be a systematic investigation of the Church Register Section (Walliser Kirchenmatrikeln) and the Family Section (Familienfonds) in the Public Record Office of the Valais (Staatsarchiv Wallis) and the archives of the villages.

Acknowledgments This research is part of project COGEAR (Coupled Seismogenic Geohazards in Alpine Regions) supported by the Competence Centre Environment and Sustainability of the ETH Domain (CCES). We acknowledge support from the projects NERIES (Network of Research Infrastructures for European Seismology, task NA4-'Distributed Archive of Historical Earthquake Data'), and the PEGASOS Refinement Project in Switzerland. We finally would like to thank our reviewers and editors who helped to improve this paper.

\section{References}

\section{Manuscripts}

StAW: Staatsarchiv Wallis.

StAW, DI, 27.3.3 Tremblement de terre de juillet 1855: Révision de la taxe, distribution des secours. Ancien fonds du département de l'intérieur. (1855-1860).

StAW, 1101, Conseil d'État 1859. Protocoles des séances du Conseil d'État 1855-1857, séance du 27. juillet 1855.

\section{Publications}

Bundesamt für Statistik. Landesindex der Konsumentenpreise. LIK Rechner. Last visited 15.07.2011. http://www.portal-stat.admin. ch/lik_rechner/d/lik_rechner.htm.
Fäh, D., Giardini, D., Bay, F., Bernardi, F., Braunmiller, J., Deichmann, N., et al. (2003). Earthquake catalogue of Switzerland (ECOS) and the related macroseismic database. Eclogae Geol Helv, 96, 219-236.

Fäh, D., Giardini, D., Kästli, P., Deichmann, N., Gisler, M., SchwarzZanetti, G., Alvarez-Rubio, S., Sellami, S., Edwards, B., Allmann, B., Bethmann, F., Wössner, J., Gassner-Stamm, G., Fritsche, S., \& Eberhard, D. (2011a). ECOS-09 earthquake catalogue of Switzerland release 2011 report and database. Public catalogue, 17. 4. 2011. Swiss Seismological Service ETH Zurich, Report SED/RISK/R/001/20110417 avalaible at http://www.seismo.ethz.ch.

Fäh, D., Moore, J., Burjanek, J., Iosifescu, I., Dalguer, L., Dupray, F., Michel, C., Woessner, J., Villiger, A., Laue, J., Marschall, I., Gischig, V., Loew, S., Marin, A., Gassner, G., Alvarez, S., Balderer, W., Kästli, P., Giardini, D., Iosifescu, C., Hurni, L., Lestuzzi, P., Karbassi, A., Baumann, C., Geiger, A., Ferrari, A., Laloui, L., Clinton, J., \& Deichmann, N. (2011b). Coupled seismogenic geohazards in alpine regions. Bolletino di Geofisica Teoretica ed Applicata (in press).

Fritsche, S. (2008). Large historical earthquakes in Switzerland: multidisciplinary studies on damage fields and site-effects. Ph.D. dissertation, ETH Zurich Nr. 17710, Zurich, Switzerland, p 239.

Fritsche, S., \& Fäh, D. (2009). The 1946 Magnitude 6.1 Earthquake in the Valais: site-effects as contributor to the damage. Swiss $J$ Geosci,. doi:10.1007/s00015-009-1340-2.

Fritsche, S., Fäh, D., \& Giardini, D. (2005). Damage fields and siteeffects. Investigations on the 1855 earthquake in Switzerland. In: Proceedings of the international conference of the 250th anniversary of the 1755 Lisbon earthquake, Lisbon, pp 340-346.

Fritsche, S., Fäh, D., Gisler, M., \& Giardini, D. (2006). Reconstructing the damage field of the 1855 earthquake in Switzerland: historical investigations on a well-documented event. Geophys $J$ Int, 166, 719-731.

Giardini, D., Wiemer, S., Fäh, D., \& Deichmann, N. (2004). Seismic hazard assessment of Switzerland, 2004. Publication Series of the Swiss seismological service, ETH Zürich, 91 pages.

Gisler, M. (2008). Nicht nur in Lissabon bebte die Erde: Das Walliser Ereignis vom 9. Dezember 1755. In M. Gisler, D. Fäh, D. Giardini, (Ed.), Nachbeben. Eine Geschichte der Erdbeben in der Schweiz. Bern, Haupt.

Gisler, M., \& Fäh, D. (2011). Grundlagen des Makroseismischen Erdbebenkatalogs der Schweiz, Band 2, 1681-1878. Zürich: Herausgegeben vom Schweizerischen Erdbebendienst.

Gisler, M., Fäh, D., \& Deichmann, N. (2004). The Valais earthquake of December 9, 1755. Eclogae Geol Helv, 97, 411-422.

Gisler, M., Fäh, D., \& Masciadri, V. (2007). "Terrae motus factus est": earthquakes in Switzerland before A.D. 1000. A critical approach. Nat. Hazards, 43, 63-79.

Gisler, M., Fäh, D., \& Giardini, D. (Ed.) (2008a) Nachbeben. In M. Gisler, G. Schwarz-Zanetti, S. Fritsche, D. Fäh, P. Kästli, Eine Geschichte der Erdbeben in der Schweiz ( $\mathrm{p} 192)$. Bern: Haupt Verlag.

Gisler, M., Kozák, J., \& Vanek, J. (2008b). The 1855 Visp (Switzerland) earthquake: a milestone in macroseismic methodology? In J. Fréchet, M. Meghraoui, M. Stucchi (Ed.), Historical seismology: interdisciplinary studies of past and recent earthquakes. Modern Approaches in Solid Earth Sciences 2 (pp. 225-241). Heidelberg.

Grünthal, G. (Ed.) (1998). European Macroseismic Scale 1998. Cahiers du Centre Européen de Geodynamics et de Séismologie. Vol. 15. Luxembourg: Conseil de L'Europe.

Heim, A. (1932). Bertsturz und Menschenleben. Zürich: Karten und Photos.

Heusser, J.C. (1856). Das Erdbeben im Visper-Thal im Jahr 1855. An die zürcherische Jungend auf das Jahr 1856. Neujahrsblätter der Naturforschenden Gesellschaft, 58. Stück. Zürich. 
Heynen, M. (2010) The influence of topographic amplification and local site conditions on the seismic stability of rock slopes (Seetalhorn, VS). Unpublished MSc Thesis Department ERDW, ETH Zürich.

Loizeau, J.-L. (1991). La sédimentation récente dans le delta du Rhône, Léman: processus et évolution, Ph.D. dissertation, Univ. Geneva, N. 2514. Geneva, Switzerland.

Nöggerath, J. (1855). Die Erdbeben im Vispthale. Besonderer Abdruck für Freunde des Verfassers aus Nr. 282 bis 286 der Kölnischen Zeitung von 1855. Köln: Selbstverlag.

Roten, D. (2007). Site effects in the Rhone valley analyzed by ambient noise, weak motion records and numerical simulations. Ph.D. dissertation, ETH Zurich Nr. 17471, Zurich, Switzerland.

Roten, D., Fäh, D., Olsen, K. B., \& Giardini, D. (2008). A comparison of observed and simulated site response in the Rhone valley. Geophysical J Int, 173(3), 958-978.

Schwarz-Zanetti, G. (2008a). Erdbebenserie mit Flutwelle und Bergsturz vom 11. bis 14. März 1584 im Genferseegebiet. In
M. Gisler, D. Fäh, D. Giardini (Ed.), Nachbeben. Eine Geschichte der Erdbeben in der Schweiz. Bern, Haupt.

Schwarz-Zanetti, G. (2008b). Das Wallis bis 1700: eine seismologische Terra incocnita? In M. Gisler, D. Fäh, D. Giardini (Ed.), Nachbeben. Eine Geschichte der Erdbeben in der Schweiz. Bern, Haupt.

Schwarz-Zanetti, G., \& Fäh, D. (2011). Grundlagen des Makroseismischen Erdbebenkatalogs der Schweiz, Band 1, 1000-1680. Zürich: Herausgegeben vom Schweizerischen Erdbebendienst.

Volger, O.G.H. (1856). Untersuchungen über das letztjährige Erdbeben in Central-Europa. Mittheilungen aus Justus Perthes' geographischer Anstalt über wichtige neue Erforschungen auf dem Gesammtgebiete der Geographie (pp. 12-100). Von Dr. A. Petermann.

Wanner, E., \& Grütter, M. (1950). Etude sur les répliques de tremblement de terre du Valais, de 1946 à 1950. Bulletin de la Murithienne, fasc (pp. 24-41). LXVII. 